Section Editor

John J. Millichap, MD

\title{
Teaching Video NeuroImages: Foville syndrome
}

回

Chindhuri Selvadurai

M. William Rondeau, PA-C

Rene A. Colorado, MD, $\mathrm{PhD}$

Steven K. Feske, MD

Sashank Prasad, MD

Correspondence to

Dr. Prasad:

sprasad2@partners.org

\section{Figure Foville syndrome}
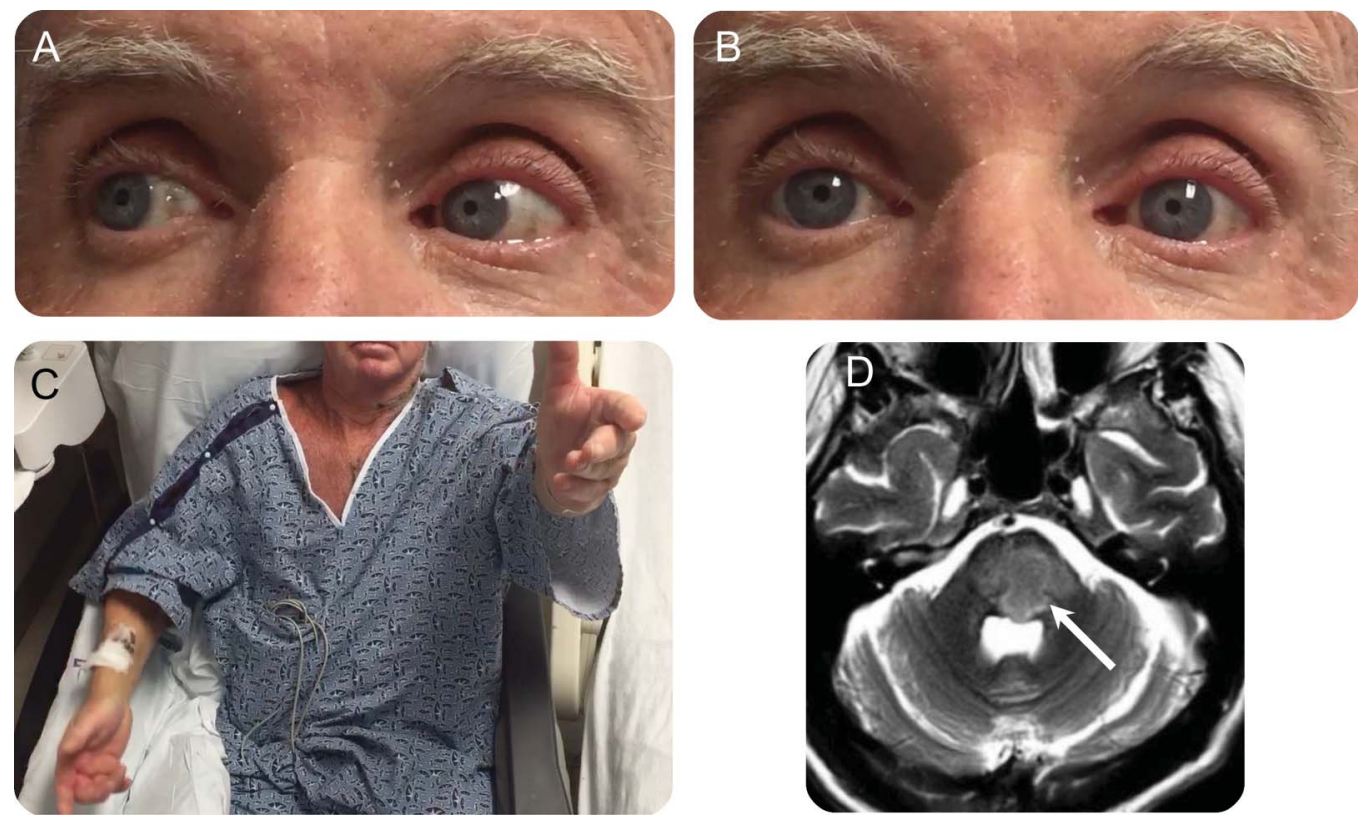

(A) Normal right gaze. (B) Complete horizontal left conjugate gaze palsy. (C) Right hemiparesis. (D) T2-weighted axial MRI with acute hemorrhage in the pons extending dorsally and to the left (arrow).

A 68-year-old man with a pontine telangiectasia on anticoagulation developed a left conjugate gaze palsy and right hemiparesis (figure; video on the Neurology ${ }^{\circledR}$ Web site at Neurology.org). Brain MRI showed acute pontine hemorrhage extending dorsally and to the left.

After seeing a similar patient in 1858 , Foville ${ }^{1}$ inferred that a lesion in the left dorsal pons affected the descending corticospinal tract before its decussation and the structures innervating the left lateral and right medial recti. He developed the concept of conjugate gaze to explain how "antagonistic muscles, which are innervated by different nerves, cooperate in a single action" (authors' translation). The complete syndrome described by Foville also includes an ipsilateral fascicular facial palsy.

\section{AUTHOR CONTRIBUTIONS}

Chindhuri Selvadurai assisted with clinical care of the patient, drafted the manuscript, and edited figure content. M. William Rondeau assisted with clinical care of the patient and with filming the video content. Dr. Rene Colorado assisted with clinical care of the patient. Dr. Steven Feske translated the original article from French and revised the manuscript. Dr. Sashank Prasad assisted with filming the video content, revised the manuscript, and edited film and figure content.

\section{STUDY FUNDING}

No targeted funding reported.

\section{DISCLOSURE}

The authors report no disclosures relevant to the manuscript. Go to Neurology.org for full disclosures.

\section{REFERENCE}

1. Foville A. Note sur une paralysie peu connue de certains muscles de l'oeil, et sa liaison avec quelques points de l'anatomie et la physiologie de la protubérance annulaire. Bull Soc Anat Paris 1858;33:393-414.

\section{Supplemental data at Neurology.org}

Download teaching slides: Neurology.org

From the Department of Neurology, Brigham and Women's Hospital, Harvard Medical School, Boston, MA. 


\section{Neurology}

Teaching Video NeuroImages: Foville syndrome

Chindhuri Selvadurai, M. William Rondeau, Rene A. Colorado, et al.

Neurology 2016;86; 203

DOI 10.1212/WNL.0000000000002658

This information is current as of May 9, 2016

\section{Updated Information \& Services}

Supplementary Material

\section{References}

Subspecialty Collections

Permissions \& Licensing

Reprints including high resolution figures, can be found at: http://n.neurology.org/content/86/19/e203.full

Supplementary material can be found at: http://n.neurology.org/content/suppl/2016/05/08/WNL.0000000000002 658.DC1

http://n.neurology.org/content/suppl/2016/05/08/WNL.0000000000002 658.DC2

This article cites 1 articles, 0 of which you can access for free at: http://n.neurology.org/content/86/19/e203.full\#ref-list-1

This article, along with others on similar topics, appears in the following collection(s):

All Cerebrovascular disease/Stroke

http://n.neurology.org/cgi/collection/all_cerebrovascular_disease_strok $\mathrm{e}$

Clinical neurology examination

http://n.neurology.org/cgi/collection/clinical_neurology_examination Ocular motility

http://n.neurology.org/cgi/collection/ocular_motility

Information about reproducing this article in parts (figures,tables) or in its entirety can be found online at:

http://www.neurology.org/about/about_the_journal\#permissions

Information about ordering reprints can be found online:

http://n.neurology.org/subscribers/advertise

Neurology ${ }^{\circledR}$ is the official journal of the American Academy of Neurology. Published continuously since 1951, it is now a weekly with 48 issues per year. Copyright () 2016 American Academy of Neurology. All rights reserved. Print ISSN: 0028-3878. Online ISSN: 1526-632X.

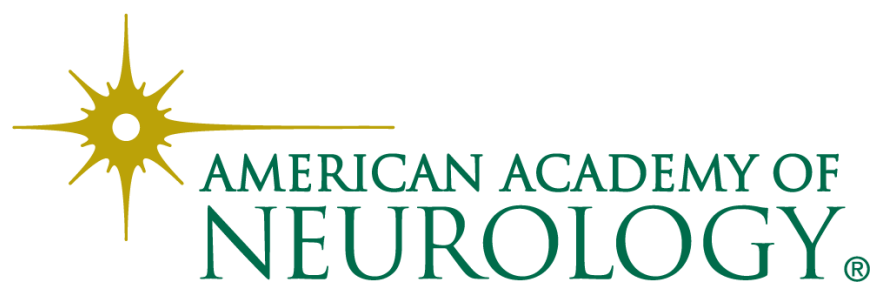

